\title{
Communication Media Policy and Regulation: Implications for Mainstreaming e-Learning in Nigeria
}

\author{
Adeyinka Olumuyiwa Osunwusi (corresponding author) \\ Department of Educational Foundations, Faculty of Education, \\ National Open University of Nigeria (NOUN) \\ 14-16, Ahmadu Bello Way, Victoria Island, Lagos, Nigeria \\ E-mail: aosunwusi@yahoo.com
}

Tel: 234-802-979-7493/234-806-746-1324

Received: July 7, 2019 Accepted: August 15, 2019 Published: August 21, 2019

doi:10.5296/ijld.v9i3.15033 URL: https://doi.org/10.5296/ijld.v9i3.15033

\begin{abstract}
Issues bordering upon the imperativeness of communication media policy and regulation are, perhaps, no longer open to debate. Although media and communication governance remains a largely national prerogative, principles, policies and regulations - albeit essentially normative in nature - exist for the administration and regulation of media and communication at inter-governmental and global levels, consequent upon the progressive evolution of new digital technologies, the increasing universality of media access, the paradigm shift towards communication system interoperability and automation, the stride towards virtualization, and the emerging trends in the digitalization of knowledge. This body of policies, principles and regulations expectedly has a bearing on communication media applications, services, and tools. Emerging trends in training, development and the teaching-learning processes globally reveal a frenzied shift towards the application of digital technologies to facilitate the effectiveness, efficiency, and liberalization of learning. This paper undertakes an overview of international media policy and regulatory framework within the context of national media and communication policy frameworks. It analyses a number of existing and emerging issues in media and communication regulation and examines the implications of these issues on the digitalization of knowledge on one hand and the stride toward mainstreaming e-learning within the context of the Nigerian educational realm on the other hand. Recommendations were also advanced for the mainstreaming of e-learning in Nigeria against the backdrop of national and international media and communication governance frameworks.
\end{abstract}


Keywords: Media policy, e-learning, education, communication media regulation, media governance, ICT, digital technologies.

\section{Introduction}

Communication and media governance as a system of institutionalized and organized regulatory and policy mechanisms for the administration of the communication and media industry remains a largely national prerogative and essentially state-oriented with regulatory systems and institutional frameworks that are largely tied to national sovereignty and subject, as a result, to strict national governance.

This notwithstanding, principles, policies and standardization frameworks exist at the global levels for the administration and regulation of a wide range of technical and non-technical issues bordering upon media and communication. There are also international bodies such as the World Summit on the Information Society (WSIS) and the International Telecommunication Union (ITU). Scholars such as Raboy and Padovani (2010) have, however, argued that national sovereignty is no longer absolute consequent upon the ongoing development of new strategies, new institutional models, new forms of trans-national collaboration and new networks of point-to-point communication coupled with the emergence of new global approaches to public policy.

The need for global frameworks for communication and media governance is clearly underscored by the increasing need for sustainable and strategic cooperation among national, regional and international actors. This need is, in turn, being driven by a plethora of contemporary issues including the rapid increases in connectivity, the emergence of new digital technologies, the global penetration of media, the interoperability and automation of communication systems, and the continuing emergence of a wide variety of common issues relating to copyright, technology convergence, virtualization, cyber security, cyber resilience, internet governance, digitalization of knowledge, and media content policy.

The increasing shift towards digitalization also clearly underscores the relevance of global media policy as digitalization - transformational processes enabled by the new technologies spreads its tentacles across all sectors of our economy and society. In the education sector, digitalization is changing the way we design pedagogy, the way we conceptualize both andragogy and heutagogy, the way we teach, the way we learn, and the way we package, store, and share knowledge.

This paper undertakes an examination of media and communication governance and a discussion of the implications of this for mainstreaming e-learning in Nigeria against the backdrop of critical issues surrounding media and communication governance.

\section{Statement of the Problem}

The world is undoubtedly in the firm grip of a frenzied digital revolution, characterized by rapid evolution and deployment of new digital technologies, tools, applications, and services, which have direct impacts on every aspects of human activity. New network functionalities and service capabilities are being implemented for both data and voice, including "improvements 
to both downlink and uplink speeds and new ways to efficiently deliver content at a certain quality level" (Ericsson, 2015) just as the advent of the Internet and innovative technological tools created first e-learning, then m-learning, and finally, u-learning (Bozkurt et al, 2017) and new technologies ushered in a multichannel communication age (Sun et al, 2011). Digital technology, according to Talabi (2011), "allows both traditional and new communication services - whether voices, data, sound or pictures - to be provided over many different networks". Ericsson (2015) projects that 90 percent of the world's population over 6 years old will have a mobile phone by 2020, with mobile broadband, smartphone and WCDMA/GSM subscriptions projected to climb to 7.7 billion, 6.1 billion, and 3.8 billion globally by 2020 respectively. Ericsson also predicts that almost 80 percent of smartphone subscriptions added during 2015-2020 will be from Asia Pacific, the Middle East and Africa (Ericsson, 2015).

There is no gainsaying the fact that the growth of digital technologies will have tremendous impact on the orientation of media policy and regulation. Questions have, however, arisen surrounding the relevance of regulation in the digital age in respect of a vast majority of issues including copyright and the principle of "fair use". The increasing universalization of media also appears to be re-writing the books in terms of issues surrounding libel, defamation, slander and the question of the right of reply.

The transformational effect of the ongoing strides towards digitalization on the education-training landscape is becoming increasingly noticeable. One particularly significant outcome is the fact that digitalization of knowledge is fast becoming a buzzword. Given the fact that e-learning, an aspect of knowledge digitalization, thrives on the new technologies and the fact that the healthy evolution of the new technologies revolve around efficient, effective and sustainable policy and regulatory frameworks, the questions that become relevant in the light of the subject-matter of this paper are:

- What are the characteristics of the global media policy environment and what structures and frameworks are institutionalized for communication and media regulation at national and global levels?

- What are the critical issues surrounding media policy and regulation and what are the implications of these issues on e-learning and the digitalization of knowledge?

- How do existing and emerging new technologies impact the communication and media policy sphere?

- What are the critical elements of the e-learning space and how are they impacted by the new technologies?

\section{Objectives}

The overall aim of this paper is to undertake an overview of national and global media policy and regulation frameworks with a view to determining the impacts of critical issues surrounding media policy orientation on the digitalization of knowledge and the mainstreaming of e-learning within the context of the Nigerian education system. 
More specifically, the paper seeks to:

i. evaluate the impacts of existing and emerging media policy and regulation-related issues on the efficient integration of the new technologies in educational activities;

ii. examine the characteristics of global media policy environment vis-à-vis their implications for mainstreaming e-learning;

iii. examine the core elements of the e-learning space vis-à-vis the dynamics of digitalization; and

iv. determine the effects of the increasing universalization of media on the orientation of media regulation.

\section{Literature review}

\subsection{Conceptual Framework of the e-Learning Space}

E-learning, as an innovative approach to delivering, monitoring and evaluating instructions in line with clearly defined instructional design and delivery principles and strategies, essentially thrives on technologies. It is largely based on Internet technology and considerably dependent on Internet connectivity. Consequently, communication media policy should have a bearing on e-learning.

The term 'e-Learning' has been subjected to a wide variety of definitions and conceptualizations. It has been defined as the convergence of the internet and learning or as Internet-enabled learning (Ajadi et al, 2008), the use of computer and Internet technologies to deliver a broad array of solutions to enable learning and improve performance (FAO, 2011, p. 3), learning utilizing electronic technologies to access educational curriculum outside of a traditional classroom (eLearning North Carolina), "a computer based educational tool or system that enables you to learn anywhere at any time" (Epignosis, 2014), and the use of information and communication technologies to enable access to online learning/teaching resources (Arkorful \& Abaidoo, 2014).

There are also several shades of conceptualization of e-learning particularly in terms of its components. The eLearning North Carolina argues that e-learning is an interactive course that is specifically delivered via the internet and not a course delivered via a DVD or CD-ROM, video tape or over a television channel. Although Islam (1997), cited by Ajadi et al (2008), has conceptualized the applications and process of e-learning to include "computer-based learning, web-based learning, virtual classroom and digital collaboration where content is delivered via the internet, intranet/extranet, audio and/or video tapes, satellite TV and CD-ROM", Epignosis LLC (Epignosis, 2014) argues that, while e-learning is mostly delivered today through the internet, the delivery of e-learning using a blend of computer-based methods like CD-ROM belongs to the past. Anderson (2005), however, prefers to conceptualize e-learning as being broader than online learning since, in his words, "it includes all electronic media, like CD-ROM and DVD for instance, both of which are off-line media, as well as web technologies". Essentially and generally, the components of e-learning are: e-learning content, e-tutoring, e-coaching, e-mentoring, collaborative learning, and virtual classroom (FAO, 2011, 
p. 11).

In terms of the modes of channeling information or communication, e-learning has been divided into two broad flavors, namely asynchronous e-learning and synchronous e-learning. Asynchronous e-learning refers to online learning situations or events that are essentially time-independent or that are not carried out in real time. They are, therefore, non-live and students have the freedom of engaging in learning over a time gap and at their own pace. Examples of asynchronous e-learning events are self-paced learning situations carried out via e-mail, discussion forums, Wiki, Blog or Webcasting (FAO, 2011, p. 13). Synchronous e-learning, on the other hand, involves online learning events or situations that take place in real time and are, therefore, essentially time-dependent. Synchronous communication between two people requires them to both be present at a given time (FAO, 2011, p. 13). Keegan et al (2005), cited by Holmstrom and Pitkanen (2012), submit that synchronous communication enables students to watch teachers' presentations and verbally interact with the teachers during learning sessions.

E-learning is known to be much more appropriate when the training is aimed at building cognitive skills, involving knowledge and comprehension, rather than psychomotor skills (FAO, 2011, p. 9). Although e-learning is known to be applicable at all levels of education and training, it, normally, has been practiced in higher education and corporate and occupational training as a part of lifelong learning (eLearn Center, 2018), while some institutions in Nigeria are presently using it to promote distance education and lifelong learning with the CD-ROM containing lecture notes being the commonest type of e-learning adopted (Ajadi et al, 2008).

Whereas e-learning has been implemented, to a considerable extent, as a tool in the education and training systems of developed countries, Sife, Lwoga and Sanga (2007), cited by Holmstrom and Pitkanen (2012), observe that many developing countries' efforts to take up e-learning in higher education are still at a preliminary stage. The situation is quite regrettable in Africa in general and Nigeria in particular. Ajadi et al (2008) sum up the Nigerian situation thus:

Here in Nigeria, very few of our conventional universities are now carrying out their academic activities through one form of ICT or the other while the urge to embark on e-learning is still a dream to some because their infrastructure of ICTs is very weak.

\subsection{The Media Policy Space}

Media systems around the world are in rapid flux today, according to Hallin (2005), "as changes in technology and market structure disrupt media institutions that had evolved over many decades". As Zaballos (2017) has also rightly painted the picture:

The digital revolution is transforming our societies at an unstoppable pace. From finance to education, health and government, virtually every sector or activity is being changed thanks to technology.

The resultant effect of the increasing presence of the digital revolution is a renewed interest in the commitment towards connecting the world. One way in which this interest is playing out is 
the rapid shift of interest towards issues bordering upon broadband networks as the basic connection-enabling infrastructure. Today, broadband is increasingly seen as a utility rather than a commodity (Ofcom, 2017). The Secretary-General of the International Telecommunication Union (ITU), Houlin Zhao, sums up the significance of broadband networks in this way:

Broadband networks offer perhaps the greatest opportunity we have ever had to make rapid and solid advances in global social and economic development - across all sectors, including healthcare, education, new job opportunities, transportation, agriculture, trade and government services. In the twenty-first century, broadband networks therefore need to be considered as basic critical infrastructure, like roads, railways, water and power networks (International Telecommunication Union, 2019a).

The fundamental issue in relation to global discourse in the context of global media governance appears to be issues surrounding the increasing universalization of media, which questions the relevance of regulation and points to the fact that media is global in nature or the existence of what can be safely referred to as a global media culture. But, Sparks (2000), cited by Jan (2009), has opined rather frankly that no media is indeed genuinely global in nature. Where there is anything that can be rightly described as the "Globalization of media", this is, according to Jan (2009), "probably most pervasive at the level of media industry models - ways of organizing and creating media".

When conceptualized in the context of communication and media governance, the question that arises is whether the governance processes and characteristics are pervasive at the local or national levels or whether they traverse national boundaries, thus reflecting a convergence or a sort of "global interconnectedness". Raboy and Padovani (2010) have opined that globalization in relation to global media policy does not just refer to a supra-national or transnational space involving interactions among a variety of actors, but also refer to "the multi-layered realities of communication systems, networks and regulation".

In terms of media culture, differences expectedly exist between national media systems, particularly when the whole issue for debate is conceptualized under the realm of the mass media, specifically the broadcasting media. This notwithstanding, the question of where these differences come in and where they actually stand when it comes to the issue of global media culture is still open to debate. According to Hallin (2005), "It is common today to talk about the creation of a global media culture, mainly based on the American model, which would overwhelm national differences in media systems".

Interestingly, the question of whether there are differences in national media systems or the existence of overwhelming influence on the part of a particular national media system commands attention towards issues surrounding what is often referred to as the Global Media Policy. Curiously, the global media and communication governance environment is a very complex and dynamic space, which plays host to different national media and communication entities with varying degrees of influence. This atmosphere of different degrees of influence among actors in the media and communication policy realm no doubt has implications for national and trans-territorial peculiarities and interests. It also exercises a bearing upon the 
main issues surrounding media and communications.

\section{Global and National Dimensions of Communication and Media Governance}

The International Telecommunication Union (ITU) is a key player in global media and communication technologies governance, handling issues bordering upon the definition and development of technical standards for radio communication and interconnectivity of technologies and networks, satellite orbital slot/frequency allocation, and global radio spectrum management. According to the ITU, the global body "is the premier global forum through which parties work towards consensus on a wide range of issues affecting the future direction of the ICT industry" (International Telecommunication Union, 2019b).

Operationally, ITU's framework is segmented into three broad activity areas: Radio Communications (ITU-R), which handles the international management of radio frequency spectrum and satellite orbits; Telecommunication Standardization (ITU-T) for the definition and establishment of standards - which are essentially recommendations - for transport protocols, telephony, internet access, voice/video compression, and networking; and Telecommunication Development (ITU-D), which facilitates access to telecommunications with a view to stimulating "broader social and economic development".

A greater chunk of ITU's work and activities are conducted in Study Groups with specific areas of focus targeted at defining and establishing frameworks for ensuring optimum operation of all services. The study groups normally work towards defining and establishing technical standards or guidelines, which are referred to as international recommendations. Aside from the study groups, there are also Focus Groups, which provide the forum for addressing urgent issues that are outside the mandate of existing study groups.

Another key player in global media policy, information and cooperation is the World Intellectual Property Organization (WIPO). With the mission of leading "the development of a balanced and effective international intellectual property (IP) system that enables innovation and creativity for the benefit of all" (World Intellectual Property Organization, 2019a), WIPO "provides a global policy forum, where governments, intergovernmental organizations, industry groups and civil society come together to address evolving intellectual property (IP) issues" (World Intellectual Property Organization, 2019b).

WIPO's activities in areas bordering upon ICT and copyright issues incorporate, inter alia, dispute arbitration/mediation and intellectual property protection covering a wide variety of interest areas such as Mobile Apps, software development, system integration, software licensing, film and media, broadcasting, telecommunications, and TV formats. Through its Uniform Domain Name Dispute Resolution Policy (UDRP) initiative and the WIPO Arbitration and Mediation Center, WIPO also offers special procedure that allows trademark owners to resolve cybersquatting issues. There are also a number of WIPO conventions and treaties that focus on issues relating to media and communication. The Brussels Convention Relating to the Distribution of Programme-carrying Signals Transmitted by Satellite (Brussels Convention 1974), for example, focuses on measures to prevent the unauthorized distribution on or from the territory of a Contracting State of any programme-carrying signal transmitted by 
satellite.

\subsection{The US Media Governance Model}

The United States of America's media and communication regulation revolves around the Federal Communications Commission (FCC), a US government independent agency created by statute to regulate interstate and international communications by radio, satellite, television, wire, and cable in all the states of the US, the District of Columbia and other US territories.

The FCC is responsible, among other things, for: developing, implementing, and revising communications and media regulations; encouraging effective and efficient use of spectrum domestically and internationally; handling applications for licenses and other filings; and encouraging the development of innovative services as well as promoting competition, innovation and investment in broadband services and facilities.

FCC's activities cover the entire spectrum of media and communication governance. For this reason, the commission is organized into functional bureaus and offices, including the Wireless Telecommunications, Wireline Competition, Consumer and Governmental Affairs, Enforcement, Public Safety and Homeland Security, International and Media Bureaus as well as offices responsible for functional areas such as Communications Business Opportunities, Engineering/Technology and Media Relations. Each FCC bureau incorporates a number of divisions handling specific regulatory tasks. For example, the Media Bureau regulates broadcast radio and television and comprises the Audio Division - which handles issues relating to licenses for commercial and noncommercial educational AM, FM, FM Translator, FM Booster, and educational low power FM - and the Video Division, which regulates digital television broadcasting, including commercial and noncommercial educational $\mathrm{TV}$, low power TV, Class A TV, TV Translators and TV Booster broadcast services.

\subsection{The UK Media Governance Model}

Media and communications regulation in the United Kingdom (UK) revolves around the Office of Communications (Ofcom), established by the UK's Communications Act 2003. Ofcom gained full regulatory powers on $28^{\text {th }}$ December 2003, thus inheriting the duties of the erstwhile Office of Telecommunications (Oftel), the Independent Television Commission, the Radio Authority, and the Radiocommunications Agency.

Ofcom is responsible for regulating the whole spectrum of UK's media and communication sector bordering upon a wide range of functions including regulation of electronic communications networks and services, the management of electro-magnetic spectrum, regulation of radio and television broadcasting, and the regulation of newspaper and other media enterprises.

The UK Communications Act 2003 as well as the amendments thereto is unique in the sense that it, among other things: integrates telecommunications and broadcasting regulation under one regulator - Ofcom; confers on Ofcom, through the Digital Economy Act of 2010, the responsibility of enforcing regulations concerning Internet copyright breaches; provides for the prohibition of political advertising on television or radio; criminalizes the act of obtaining 


\section{MInstitute Macrothink $_{\text {Int }}$}

access to the internet without the intention to pay for the service pursuant to Section 125 of the Act; gives legal recognition to community radio as a distinct third tier of radio alongside commercial radio and BBC Radio; criminalizes the act of sending malicious communication via the social media; and gives Ofcom the responsibility of promoting Media Literacy.

\subsection{The Nigerian Media Governance Model}

Unlike the media and communications models existing in the UK, USA, Australia, and some other countries, which are characterized by largely integrated regulatory structures, the Nigerian media and communications regulatory model is essentially segmented with the Nigerian Press Council, established by the Nigerian Press Council Act of 1992, responsible for regulating the Nigerian press or print media, while the Nigerian Communications Commission (NCC) and the National Broadcasting Commission (NBC) regulate the telecommunications industry and the Nigerian broadcasting industry respectively. The National Information Technology Development Agency (NITDA), established by the National Information Technology Development Act 2007, has the responsibility for developing, standardizing, coordinating and regulating information technology practices and systems in Nigeria with functions, pursuant to Section 6 of the Act, including accelerating internet and intranet penetration in Nigeria, promoting internet governance, developing guidelines for the networking of public and private establishments, and developing guidelines for electronic governance as well as monitoring the use of electronic data interchange and other forms of electronic communication transactions.

The NCC has wide ranging powers to oversee the activities of telecommunications service providers in Nigeria including Internet Service Providers (ISPs). The commission also has the responsibility of developing policies and industry codes, including policies for radio frequency spectrum management with the objective of controlling and encouraging the use of spectrum as an instrument for developing telecommunication, promoting competition in the assignment of frequency, and ensuring fair and equitable allocation of spectrum. The Nigerian Communications Act 2003 provides for the establishment of a National Frequency Management Council, whose functions shall include: assisting and advising the Minister on the representation of Nigeria and carrying out ancillary functions at international and regional spectrum allocation bodies including but not limited to the International Telecommunication Union; assisting and advising the Minister on the preparation and negotiation of bilateral and multi-lateral spectrum allocation treaties; and preparing, updating and publishing, in consultation with NCC, on a regular basis a national frequency allocation table. The Act also confers NCC with the general responsibility for economic and technical regulation of the communications industry, pursuant to Section 70 of the Act.

On its part, the National Broadcasting Commission (NBC), established by Section 1 of the National Broadcasting Commission Act, Cap NII, Laws of the Federation of Nigeria 2004, has the primary responsibility for the regulation of the broadcasting industry in Nigeria and setting policies with respect thereto. The NBC, pursuant to Section 2 of the enabling Act, has extensive powers, which include the power to process and consider applications for the establishment of broadcasting stations, the power to regulate the use of spectrum for the 


\section{Macrothink}

International Journal of Learning and Development

ISSN 2164-4063 2019, Vol. 9, No. 3

broadcasting sector and the power to establish and enforce the National Broadcasting Code.

\section{Media Policy and Regulation: Main Issues and Implications for E-Learning in Nigeria}

Contemporary issues of concern in media and communication governance such as digital access, affordability, consumer vulnerabilities, copyright, content regulation, digital literacy, and infrastructure imbalance have great implications for mainstreaming e-learning. The main issues and the implications thereof with respect to mainstreaming e-learning in Nigeria can be addressed under a four-pronged regulation-related context or domain as presented in Figure 1.

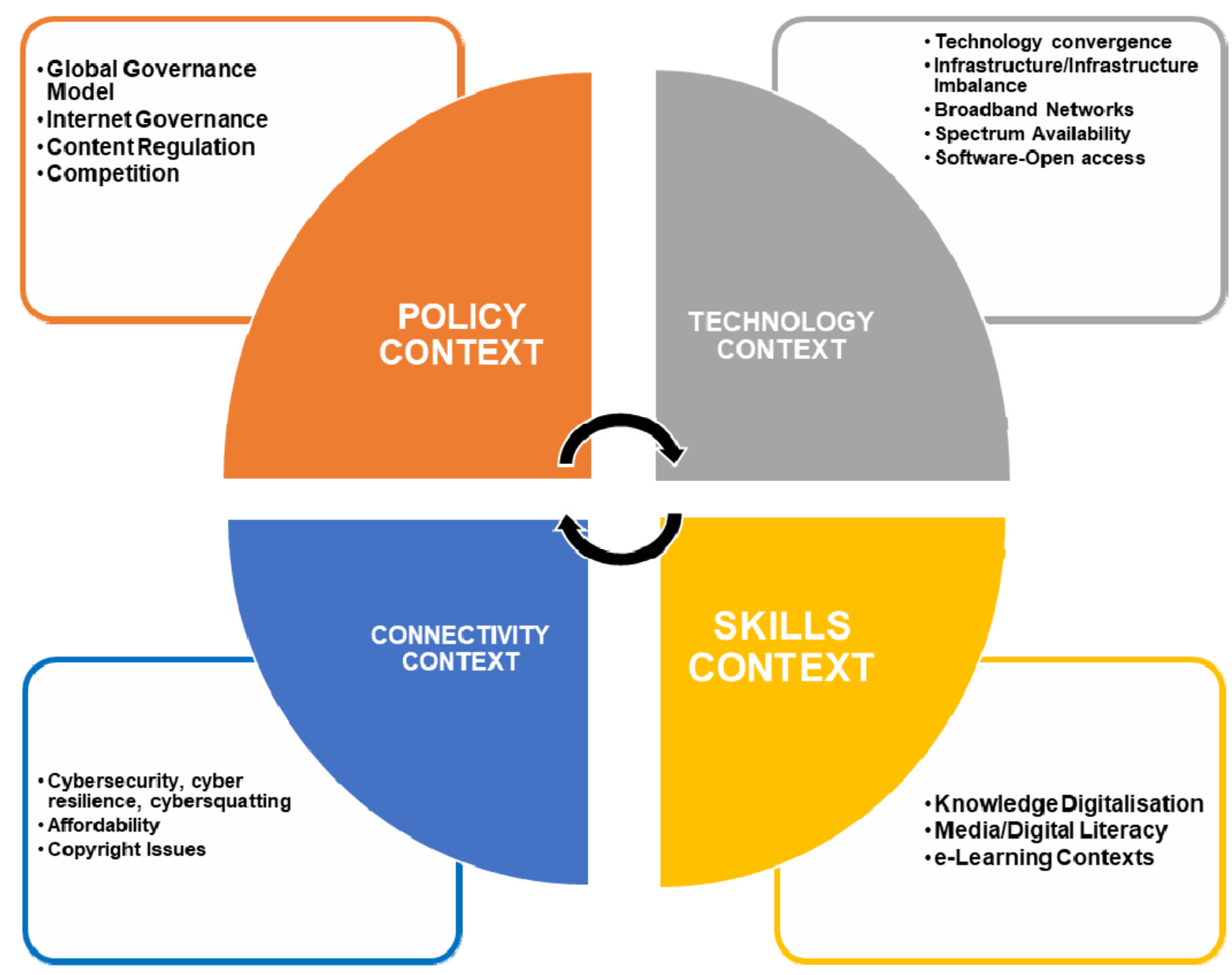

Figure 1. The Four-Pronged Component of e-Learning within the Regulatory Context

\subsection{Policy Context}

The environment in which media and communication policy is made is actually undergoing profound transformation (Raboy and Padovani, 2010). This is consequent upon the increasing fluidity of the digital technology space and the increasing paradigm shift in media governance strategies.

The global governance model for media and communication represents a complex and 


\section{MlMacrothink}

International Journal of Learning and Development

ISSN 2164-4063

2019, Vol. 9, No. 3

dynamic environment characterized by high-level politics and power play. Price (2002), cited in Raboy and Padovani (2010), describes activity within this environment as still being based on rules. The environment, according to Raboy and Padovani (2010), is "based on the interaction and interdependence of a wide array of actors and processes taking place in dispersed policy venues". It is an environment that accommodates a multiplicity of national actors whose interactions are characterized by varying degrees of autonomy and influence. The environment is also increasingly witnessing the participation of non-state actors whose roles are gaining in importance every day.

It has been observed that the environment is such that "power is not equally distributed among actors, and some sites of decision-making are more important than others" (Raboy \& Padovani, 2010). This sheer lack of equilibrium in the global media governance space have implications for media and communication administration particularly in regions such as Africa or the least developed region of the world with peculiar socio-economic, infrastructural, and developmental realities. For the mainstreaming of e-learning in Nigeria such an environment will have a bearing on a wide array of issues including access to technology, internet connectivity, content regulation orientation, spectrum availability, access to software, and the existence of an effective policy support for mainstreaming e-learning.

Aside from the peculiar characteristic of media and communication policy environment, the issue of the level of regulatory activities in a particular state or region is also very relevant as it has a direct bearing upon a regulatory authority's level of autonomy and relevance as well as the ability of a regulatory agency to set dynamic and enforceable regulatory conditions of general and universal nature.

ITU has identified five generations of regulations, as illustrated in Figure 2, ranging from the First Generation (G1) characterized by a command and control approach to the Fifth Generation (G5) with a collaborative regulatory approach that facilitates inclusive dialogue and harmonized approach across sectors. ITU's ICT Regulatory Outlook for 2017 reveals that in 2016 fewer than one in six countries belonged to G1 and one quarter of all countries were in G2, while $58 \%$ of the 189 countries covered were in G3 and G4 with G4 countries making up $28 \%$ of the countries.

A crucial element of the global communication and media governance model are Internet governance issues, which are essentially multisectoral in nature. The Tunis Agenda for the Information Society (World Summit on the Information Society, 2005, para. 35), though, recognizes the sovereign right of States with respect to Internet-related public policy issues whilst also recognizing the roles of the private sector, the civil society, intergovernmental organizations, and international organizations in Internet-related issues. 


\section{Macrothink}

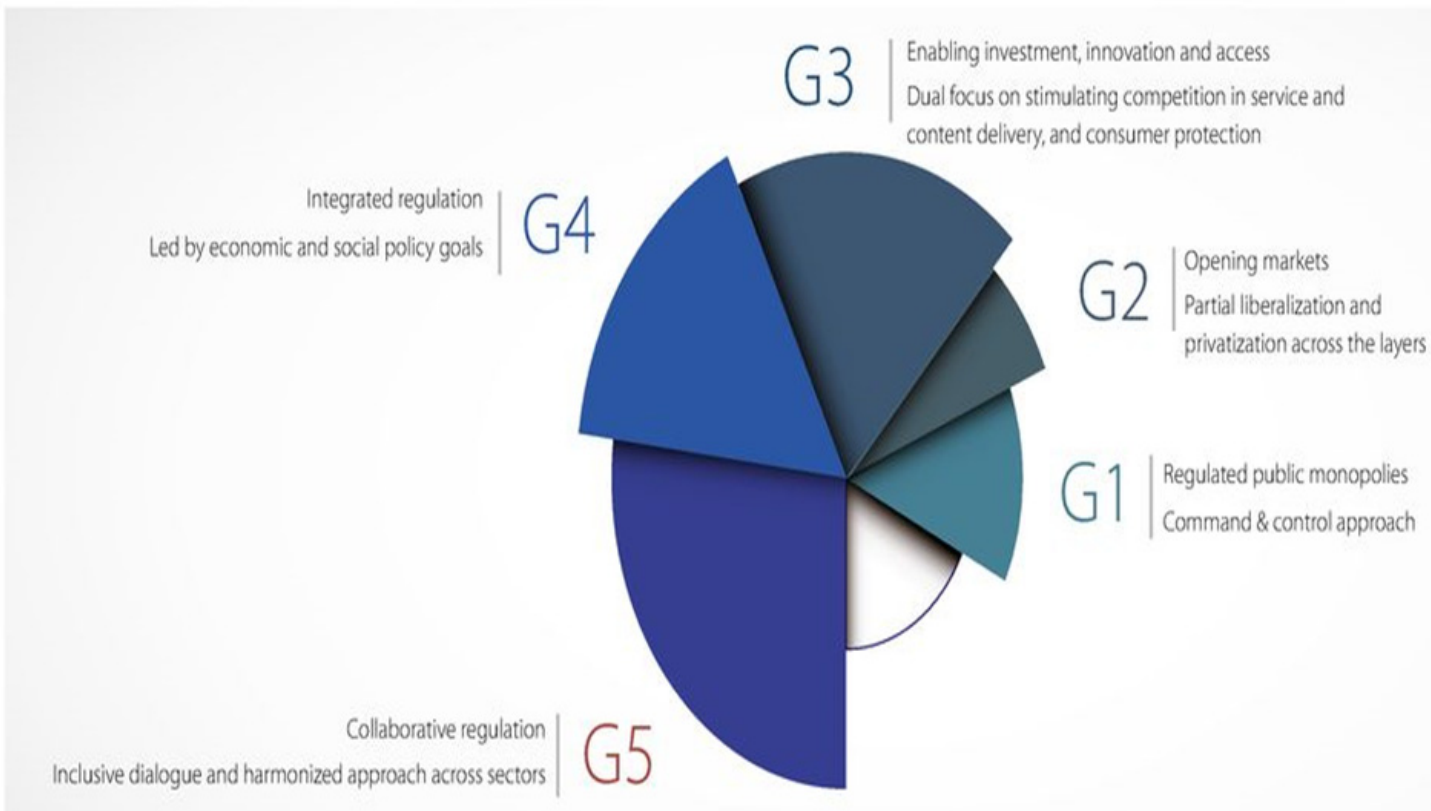

Figure 2. Generations of Regulation

Source: ITU.

In spite of the tremendous evolutionary strides of the Internet, the question of a common conceptualization of internet governance is still open to various shades of interpretation. However, the Working Group on Internet Governance, which was set up by the United Nation's Secretary-General following the mandate of the World Summit on the Information Society (WSIS) held in Geneva from 10 to 12 December 2003, has developed the following working definition:

Internet governance is the development and application by Governments, the private sector and civil society, in their respective roles, of shared principles, norms, rules, decision-making procedures, and programmes that shape the evolution and use of the Internet (Working Group on Internet Governance, 2005, p.4).

The essence of this definition is that it underscores the multilateral and transparent nature of international Internet administration and dispenses with the unilateral administration of certain processes, such as the root zone file, by a particular State, which impacts negatively on a vast majority of areas including the multilingualization of TLDs (top-level domain names) addresses and standards, the universality of Internet, the safeguarding of critical Internet resources, and facilitating access to Internet for all.

It appears - and this is a fundamental challenge for mainstreaming e-learning - that efforts in the realm of policy frameworks are restricted to technological infrastructure rather than the educational context in which technology is used. According to UNESCO:

...the organizational frameworks in which technology is used in education have not been 
treated to the same radical policy reviews as has the telecommunications infrastructure itself. Other work has to be done to establish policies concerning international trade in educational services and such related matters as institutional accreditation and assessment, certification of learning, intellectual property rights, and incentive structures (tax breaks, subsidies, promotion of public/private sector collaboration, etc.) (UNESCO, 2002, p.37).

\subsection{Technology Context}

A critical element in the mainstreaming of e-learning is the effective and efficient integration of the new technologies in educational activities. Holmstrom and Pitkanen (2012) have observed that: "For a university to be able to adopt and use e-learning in educational activities, it is preferable that sufficient resources and conditions within the organization already exist".

The growth of digital technologies has brought the need for technology convergence involving system interconnectedness either via logical infrastructures in the form of technical standards and software or physical infrastructures such as satellite networks and cables for seamless system interoperability. However, the efficiency of interoperability, which revolves around regulatory inclusiveness, constitutes an issue for mainstreaming e-learning. The capabilities of broadband networks is crucial to this and interestingly expectations regarding broadband networks and their functional capabilities are increasing. People expect to be connected everywhere through a plethora of devices (Ofcom, 2018a). The United Kingdom's Office of Communications has rightly observed that: "The increasing availability of content-rich websites, online streaming services such as Netflix and "Cloud" based applications means people and businesses increasingly expect reliable, resilient and stable broadband connections" (Ofcom, 2018b).

Within the context of technology, a number of challenges exist in Nigeria which have implications for mainstreaming e-learning. These challenges are not limited to inadequate deployment of digital infrastructure, inadequate power supply and access to and use of ICT but extend to the standard and quality of access, and unequal opportunities for effective use of the new technologies. There is also the issue of the existing digital divide and the concomitant issues of bandwidth constraints and low networks speed for which the issue of international internet bandwidth and the national backbone infrastructure are core enablers.

Notably, Nigeria, like other developing nations, lags behind in terms of international internet bandwidth, which, according to the International Telecommunication Union (2018), "is a key building block for delivering data-intensive applications and services through high-speed networks". The International Telecommunication Union (2018) notes that international internet bandwidth per inhabitant stood, as at 2016, at $140 \mathrm{kbps}$ and $53 \mathrm{kbps}$ for developed and developing regions respectively with Africa recording $51 \mathrm{kbps}$ as against $178 \mathrm{kbps}$ and $91 \mathrm{kbps}$ recorded by Europe and the Americas.

Another issue of importance is that surrounding software, which is protected under Article 4 of the World Intellectual Property Organization Treaty, 1996. Software is a core enabler in terms of getting involved in the digital space. Although free software, free online educational resources and open courseware such as the OER (Open Educational Resources) and MOOCs 
(Massive Online Open Courses) constitute critical enablers of e-learning, there is also proprietary software which is monopolized and under the exclusive control of its right-holder. The main issue with proprietary software is one of exorbitant cost that is often beyond the means of users in developing and least-developed nations.

Access to spectrum is another critical element in the integration of the new technologies into the learning system as it is related to developments of wireless broadband. A core element in spectrum availability is spectrum farming, which frees up spectrum from old technologies for use in new technologies. The International Telecommunication Union, for example, has identified the need to make available for mobile and broadband wireless services the digital dividend spectrum freed up through transition from analogue to digital broadcasting, specifically the two bands of 790-862 MHz (in ITU Region 1 covering Europe and Africa) and $698-806 \mathrm{MHz}$ (in the rest of the world) (International Telecommunication Union, 2018).

\subsection{Connectivity Context}

The quality and standard of connectivity constitute a key requirement for mainstreaming technology-savvy e-learning. Other contingent issues include connectivity costs, affordability, vulnerability issues, cyber security, cyber resilience and copyright issues.

The unresolved disparities in interconnection costs particularly in relation to Internet connectivity remain a challenge for both the developing and the least developed countries. The Working Group on Internet Governance (2005) has identified three clusters of problem in relation to this, namely: uneven distribution of costs; subjecting Internet Service Providers (ISPs) based in countries remote from Internet backbone, particularly developing countries, to paying the full cost of international circuits; and the absence of an appropriate and effective global Internet governance mechanism to resolve the issue.

Unarguably, regional cooperation on services and connectivity charges is a sine qua non in this respect in order to ensure affordability and improved connectivity. A good example is the case of the West African nations of Burkina Faso, Cote d'Ivoire, Guinea, Mali and Senegal where roaming charges no longer apply since 31 March 2017 consequent upon the signing of a Memorandum of Understanding by the regulators of the five nations (United Nations Broadband Commission for Sustainable Development, 2018).

The unrestricted nature of Internet access, save for areas where specific governmental restrictions are imposed, and the increasing prospect of cyber risks are also relevant issues. Although a regulatory cum legal framework exists in Nigeria comprising the Cybercrimes (Prohibition, Prevention, etc.) Act 2015, the Terrorism Act 2011, the NCC Internet Service Guidelines, and the Nigeria National Computer Emergency Response (ngCERT) mechanism, there is a need for the strengthening of this framework.

In terms of a variety of concern including the portability of content, issues surrounding the applicability of copyright rules in the digital age are very relevant even in the United States where the "Fair Use" rule - not applicable in Canada and the UK - allows for the limited use of copyrighted material without the right-holder's permission. 


\section{Macrothink}

Copyright rules are based on certain assumptions. But these laws, according to Litman (2006), become obsolete when technology renders the assumptions on which they were based outmoded. The core drivers include "technological advances that make content sharing extremely easy and inexpensive" (shear, 2010), revolution in the way new technology can reproduce, disseminate, and store digital information including copyrighted works (Peters, 2005), and a drastic increase in the utilization of Internet-related platforms (Shear, 2010). However, the main issues, according to Peters (2005), are technologies related to digital storage and transmission of works. These issues can exert a fourfold impact on fostering e-learning, namely: institutions will be constrained as to the materials to include in e-learning presentations; restrictions on the ability to share information as downloadable content and off-line CDs and DVDs of educational resources can constitute copyright infringement; limitations regarding how much knowledge and ideas can be extracted from other works; and the drastic curtailing of innovation as corroborated by Deloitte Access Economics (2018).

\subsection{Skills Context}

The multiplicity of digital technologies has diversified discussions surrounding issues of digital access - equitable opportunity in terms of access to and use of the digital technologies and digitalization, which Randall, et al (2018) define as "the transformation of all sectors of our economy, government and society based on the large-scale adoption of existing and emerging digital technologies".

Driven by the expectations of learners and opportunities for cooperation, digitalization is now "a reality for higher education and research" (DAAD/DIE, 2018). The digitalization of knowledge affords opportunities for knowledge diffusion and sharing. It involves digitalizing knowledge into re-usable "digital assets" with the future beckoning with the evolution of artificial intelligence (AI) and Intelligent Tutoring System (ITS).

Interestingly, skills are as important an enabler as technologies in knowledge digitalization. The ITU has rightly observed that: "Apart from high speed Internet access, learners need relatively good ICT skills, as well as language skills" (International Telecommunication Union, 2018). This underscores the imperativeness of regulatory responsibilities aimed at fostering media literacy, which has been defined as the "ability to use, understand and create media and communications in a variety of contexts" (Ofcom, 2018c). The present situation in Nigeria characterized by a lack of adequate technical and professional expertise in e-learning is, therefore, a challenge that requires a determined policy intervention.

\section{Conclusion}

Undeniably, e-learning thrives on technology and is, therefore, impacted by the vast majority of matters surrounding media policy from governance framework, technology convergence/ interoperability, and Internet governance to issues surrounding access, innovation, competition, infrastructural imbalance, affordability, copyright and interconnectivity/services costs.

There are disparities in the degree of autonomy and influence of actors in global media governance as well as the overbearing influence of certain "regulatory superpowers". This underscores the imperativeness of a more inclusive and multi-sectorial global governance 
framework.

In Nigeria there are different policy structures for particular regulatory responsibilities. For example, the Nigerian Communications Commission handles spectrum issues for the telecommunications sector while the National Broadcasting Commission handles spectrum issues for the broadcasting sector. This creates conflicts in terms of overlapping powers and responsibilities.

Finally, there are problems of access, disparities in capacities and infrastructure as well as unequal opportunities for effective use of information and communication technologies among educational institutions. Dealing with this would require the ability of the regulators to set enforceable regulatory conditions that will tackle issues of vulnerabilities, connectivity, affordability, access, and opportunities.

\section{Recommendations}

Based on the issues discussed in this paper and the conclusion thereof, a number of recommendations are necessary.

In the first instance, there is a clear need for an integration of media and communication regulatory structures in Nigeria with the convergence of regulatory authorities with overlapping powers and responsibilities.

There is the need for the creation of an atmosphere that fosters regulatory openness and inclusiveness and an atmosphere driven by regulatory regimes that keep pace with technological and market realities as well as a clear policy support for e-learning through the establishment of policies that set specific requirements for all communication service providers regarding the creation of policies and structures that cater for online learners and ICT-driven educational institutions. This will certainly require an across-the-board reformation of the nation's telecommunication policies.

Regulators need to continue to foster stronger regional and international cooperation in policy issues with a view to addressing, inter alia, the absence of an effective mechanism for global Internet governance as well as disparities including the huge differences between developed and developing regions in terms of international internet bandwidth per inhabitant. Consistent with paragraphs 8 and 9 of the Tunis Agenda for the Information Society (World Summit on the Information Society, 2005), the international community should not only actively promote technology transfer through technical cooperation and building techno-scientific capacity but also ensure the provision of adequate and sustainable investments in ICT infrastructure and services as a means of bridging the digital divide.

There is also the need on the part of government and regulators to assume a more active role in creating an enabling environment for ICT development and in facilitating media/digital literacy and innovation. This can be driven by fostering a multi-stakeholder engagement in the development of relevant policy proposals and tools as well as the development of traditional infrastructures and media such as electricity, telephone, radio and television upon which the development of the new technologies is dependent. Central to the development of 
multi-stakeholder policy proposals is the need for the institutionalization of an effective mechanism for ensuring healthy competition as well as curbing the monopolies of telecommunication entities in all forms.

Educational institutions, specifically the universities, should be critical stakeholders in mainstreaming e-learning through active engagement in policy processes, capacity building and the actual integration of information and communication technologies in educational activities. A critical element in this respect is awareness-raising aimed at significantly altering the perception of the new technologies as tools for communication rather than as enablers of development, socialization and acculturation. In line with the observation made in the UNESCO's (2002) report titled Open and Distance Learning: Trends, Policy and Strategy Considerations, it is essential to subject "the organizational frameworks in which technology is used in education" to the same "radical policy reviews as has the telecommunications infrastructure itself". As a corollary, there is also need for increased national, sub-regional, regional, and international partnerships among educational institutions, telecommunications regulators and providers, and other critical stakeholders.

Finally, regulators should be playing an active role in providing seamless mechanisms for dispute resolution and arbitration as well as in reducing taxes and tariffs on telecommunications services and products. Developing Internet backbone and reducing connectivity and data charges are central to improving access and connectedness. One of the options available involves reviewing the cost of roaming. It is on record that both the United States and Europe eliminated roaming charges since the middle of the 2000s, thus contributing to an explosion in data usage among customers travelling abroad (UN Broadband Commission for Sustainable Development, 2018).

\section{References}

Ajadi, T. O., Salawu, I. O., \& Adeoye, F. A. (2008). E-learning and Distance Education in Nigeria. The Turkish Online Journal of Educational Technology, 7(4), Art. 7.

Anderson, J. (2005). IT, e-Learning and Teacher Development. International Education Journal, ERC2004 Special Issue, 5(5). 1-14.

Arkorful, V., \& Abaidoo, N. (2014). The role of e-learning, the advantages and disadvantages of its adoption in higher education. International Journal of Education and Research, 2(12). 397-410.

Bozkurt, A., Karadeniz, A., \& Kocdar, S. (2017). Social Networking Sites as Communication, Interaction, and Learning Environments: Perceptions and Preferences of Distance Education Students. Journal of Learning for Development, 4(3), 348-365.

DAAD/DIE (2018). Digital Transformation: Higher Education and Research for Sustainable Development, Position paper. Bonn, November 2018. [Online] Available: https:// www.die-gdi.de/fileadmin/user_upload/pdfs/veranstaltungen/2018/20181217_Experts_on_Di gitalisation_in_Higher_Education_and_Research_for_Sustainability_Dec2018_final.pdf 


\section{Macrothink}

International Journal of Learning and Development

ISSN 2164-4063 2019, Vol. 9, No. 3

Deloitte Access Economics. (2018). Copyright in the Digital Age: An economic assessment of Fair Use in New Zealand (p. 39). New Zealand: Deloitte Access Economics.

eLearn Center. (2018). E-Learning Research Report 2017: Analysis of the main topics in research indexed articles (pp. 15). Barcelona: eLearn Center (OUC). http://dx.doi.org/10.7238/elc.report.2018

eLearning North Carolina. [Online] Available: https://www.eLearningNC.gov/

Epignosis (2014). E-learning: Concepts, Trends, Applications. California: Epignosis LLC. p. 5 .

Ericsson (2015). On the Pulse of the Networked Society, Ericsson Mobility Report. Retrieved June, 2015, from https://www.ericsson.com/assets/local/mobility-report/documents/ericsson-mobility-report-ju ne-2015.pdf/

FAO. (2011). E-learning Methodologies: A Guide for Designing and Developing E-learning Courses. Rome: Food and Agriculture Organization of the United Nations.

Hallin, D. C. (2005). Insights on Law and Society. American Bar Association, 5.3, Spring, $2005 . \quad$ Retrieved from www.americanbar.org/content/dam/aba/publishing/insights_law_society/mediaarticle_Insight sspring05.authcheckdam.pdf/

Holmstrom, T., \& Pitkanen, J. (2012). E-learning in Higher Education: A Qualitative Field Study Examining Bolivian Teachers' Beliefs about e-learning in Higher Education. Bachelor Thesis in Pedagogy, Spring Semester 2012, Department Of Education, Umea University, Sweden. Retrieved from https://www.diva-portal.org/smash/get/diva2:546702/FULLTEXT01.pdf/

International Telecommunication Union. (2018). Thematic Report-ICTs, LDCs and the SDGs: Achieving universal and affordable Internet in the least developed countries (pp. 11-12). Geneva: International Telecommunication Union.

International Telecommunication Union. (2019a). Broadband. Retrieved from www.itu.int/en/action/broadband/Pages/default.aspx

International Telecommunication Union (2019b). About ITU. Retrieved from www.itu.int/en/about/Pages/default.aspx

Jan, M. (2009). Globalization of Media: Key Issues and Dimensions, European Journal of Scientific Research, 29(1). 66-75.

Litman, J. (2006). Digital Copyright. ( $3^{\text {rd }}$ Ed., p. 12). New York: Prometheus Books. p. 22.

Ofcom (2017). Access and Inclusion in 2016: Outcomes for consumers in vulnerable circumstances (p. 13). UK: Office of Communications. 
Ofcom (2018a). Communications Market Report (p. 4). UK: Office of Communications.

Ofcom (2018b). Connected Nations 2018- UK Report (p. 11). UK: Office of Communications.

Ofcom (2018c). Adults' Media Use and Attitudes - Report (p. 16). UK: Office of Communications.

Peters, M. (2005). The Challenge of Copyright in the Digital Age. Retrieved from https://revistas.uexternado.edu.co/index.php/propin/article/download/1402/1337/

Raboy, M., \& Padovani, C. (2010). Mapping Global Media Policy: Concepts, Frameworks, Methods. Retrieved from June, 2010, from www.globalmediapolicy.net/sites/default/files/Raboy\&Padovani2010_long version_final.pdf

Randall L, Berlina A, Teras, J., \& Rinne, T. (2018). Digitalisation as a tool for sustainable Nordic regional developments: Preliminary literature and policy review. Discussion Paper prepared for Nordic thematic group for innovative and resilient regions, January 2018, Stockholm.

Shear, B. S. (2010). Copyright Protection in the Digital Age. Association of Corporate Counsel. $\quad$ Retrieved September 7, 2010, from www.acc.com/legalresources/quickcounsel/icpituscaeu.cfm

Sun, S., Hullman, G., \& Wang, Y. (2011). Communicating in the Multichannel Age: Interpersonal Communication Motivation, Interaction Involvement and Channel Affinity. Journal of Media and Communication Studies, 3(1), 7-15.

Talabi, F. O. (2011). The Internet and Journalism Practice in Nigeria. Global Journal of Human Social Science, 11(10), V. 1.0. 14-20.

UNESCO (2002). Open and Distance Learning - Trends, Policy and Strategy Considerations. Paris: UNESCO.

United Nations Broadband Commission for Sustainable Development (2018). Digital Entrepreneurship Working Group Report (p. 15). Geneva: International Telecommunication Union.

Working Group on Internet Governance (2005). Report of the Working Group on Internet Governance, Chateau de Bossey, June 2005. Retrieved from https://wgig.org/docs/WGIGREPORT.pdf

World Intellectual Property Organization (2019a). About WIPO. Retrieved from https://www.wipo.int/about-wipo/en/

World Intellectual Property Organization (2019b). Policy. Retrieved from https://www. wipo.int/policy/en/index.html\#bodies/

World Intellectual Property Organization (WIPO) Copyright Treaty (WCT) 1996. 


\section{Macrothink}

International Journal of Learning and Development

ISSN 2164-4063 2019, Vol. 9, No. 3

World Summit on the Information Society. (2005). The Tunis Agenda for the Information Society. Retrieved November 18, 2005, from https://www.itu.int/net/wsis/doc2/tunis /off/6rev1.html/

Zaballos, A. G. (2017). Regulatory frameworks: the key to meeting connectivity Challenges. Retrieved September 4, 2017, from https://telecomworld.itu.int/blog/third-ministerial-meeting-in-busan-connectivity-challengesand-Priorities/

\section{Copyright Disclaimer}

Copyright for this article is retained by the author(s), with first publication rights granted to the journal.

This is an open-access article distributed under the terms and conditions of the Creative Commons Attribution license (http://creativecommons.org/licenses/by/4.0/). 